International Journal of Clinical Dermatology \& Research (IJCDR)

ISSN 2332-2977

\title{
A Rare Pathology of Postauricular Region: Apocrine Hidrocystoma
}

\section{Case Report}

Gurkan Kayabasoglu $\mathrm{MD}^{1 *}$, Oznur Akidil MD ${ }^{1}$

${ }^{1}$ Ministry of Health Sakarya Training and Research Hospital, Department of Otorhinolaryngology Head and Neck Surgery Department, Sakarya, Turkey.

\begin{abstract}
Apocrine histocyctoma in the postauricular region is a very rare antity. Apocrine hidrocystomas which arise from the proliferation of apocrine glands are commonly a solitary mass diameter of $3-15 \mathrm{~mm}$ and located in periorbital region and axilla. It is very rare for apocrine hidrocyctoma to locate in postauricular region. The management of these lesions are extensive surgical excision. A 47 years old woman attended to our outpatient clinic with a painless mass in retroauricular region whose physical examination revelaed a mass consisting of conglomerating, flesh colored, multiple vesicules aproximately $10 \times 15 \mathrm{~mm}$ in diameter. In this paper, we present a case whose histopathological examination diagnosed apocrine hidrocyctoma after extensive surgical examination.
\end{abstract}

Key words: Apocrin glands, postauricular region, benign head and neck mass

\section{*Corresponding Author:}

Gurkan Kayabasoglu MD

Ministry of Health Sakarya Training and Research Hospital,

Department of Otorhinolaryngology Head and Neck Surgery,

Sakarya Adnan Menderes Cad. No: 145 Adapazar1,

Sakarya, Turkey.

Tel : 05324981854/02644445454

Email : kayabasoglu@yahoo.com

Received: August 10, 2014

Accepted: September 30, 2014

Published: September 30, 2014

Citation: Gurkan Kayabasoglu MD, Oznur Akidil MD (2014) A Rare Pathology of Postauricular Region: Apocrine Hidrocystoma. Int J Clin Dermatol Res. 2(6), 34-36, doi: http://dx.doi.org/10.19070/23322977-1400010

Copyright: Gurkan Kayabasoglu MD ${ }^{\mathbb{0}}$ 2014. This is an open-access article distributed under the terms of the Creative Commons Attribution License, which permits unrestricted use, distribution and reproduction in any medium, provided the original author and source are credited.

\section{Introduction}

Hidrocystomas are adnexal tumors that contain cystic proliferations of apocrine or eccrine secretory glands and commonly occurs as a solitary cystic intradermal lesion as a result of proliferation of apocrine glands [1]. These apocrine glands lie in the dermis and are comprised of an inner columnar, eosinophilic epithelium which is surrounded by an outer layer of myoepithelial cells it is extremely rare for this tumor to develop in the deep tissue. The excessive secretion of the glands cause glandular dilatation. The secretion is strongly PAS positive. The function of eccrine sweat glands is to help regulate the body heat and fluid but the apocrine sweat glands contribute to this function to a lesser degree. Apocrine cystic lesions with true papillary projections are referred to as apocrine cystadenoma rather than apocrine hidrocystoma [2]. Here we present an unusual localisation for apocrin hidrocyctoma; postauricular region.

\section{Case report}

A 47 years old woman attended to our outpatient clinic with a painless mass in retroauricular region. The mass was consisting of conglomerating, flesh colored, multiple vesicules and 10X15 mm in diameter (figure 1). The patient went excisional biopsy of the mass with $3 \mathrm{~mm}$ surgical margins. The histopathological examination revealed apocrine hidrocyctoma, a rare pathologic diagnose for this region (figure 2-3). After six months follow up, the patient was without complication or recurrence.

\section{Discussion}

Apocrine hidrocystomas are rare, slow growing benign cystic proliferations of the apocrine secretory glands. Although their pathophysiology remains unclear, it is thought to be due to congestion of a sweat duct resulting in a dilated cystic structure. Apocrine hidrocyctomas occur most often in adults with no age or sex predilection[3]. Our patient was a 47 year old woman. They are typically found in the head and neck, especially in the periorbital region, but other locations including the chest, axilla, palms, and penis have been described. The postauricular region is an extremely rare location for this lesion [4]. Ioannidis et all in 2008 reported the first case of external auditory canal hidrocystoma. Hidrocystomas rarely exceed $20 \mathrm{~mm}$. Tumors greater than $20 \mathrm{~mm}$ in diameter may be called "giant" apocrine hidrocystoma. The lesion of our patient was 10X15 mm in diameter so can be defined as large sized. Apocrine hidrocyctomas tends to occur as single lesions so multiple apocrine hidrocystomas seem to be uncommon [5] . Recently in 2013, Vani et all reported a multiple apocrine hidrocystoma case and represented that the presence of multiple hidrocystomas may be a marker of two rare inherited disorders the Schopf-Schulz-Passarge syndrome and the Goltz-Gorlin syndrome. The color of the lesion varied from skin-colored to light red, brown, blue, or purple. The lesion of our patient was single and flesh coloured. As we mentioned earlier because these apocrine glands lie in the dermis it is extremely rare for this tumor to develop in the deep tissue [6]. Our lesion was nearly $6 \mathrm{~mm}$ raising from the surface. 
Figure 1. Conglomerating, flesh-coloured, multiple vesicules located in postauricular region

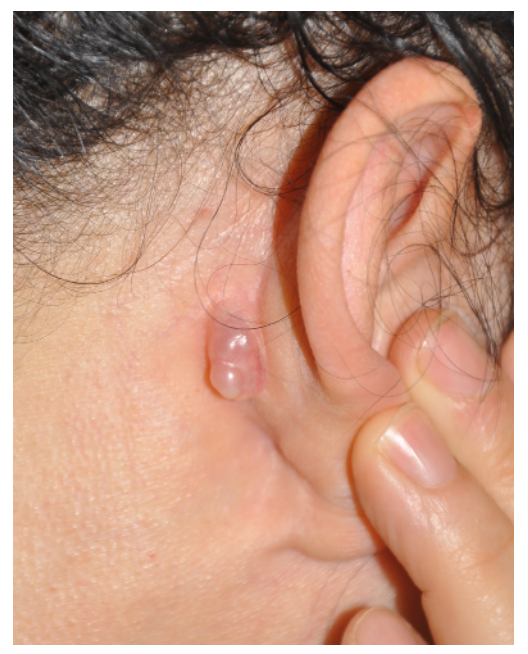

Figure 2. Apocrin hidrocystoma consisting of large multilocular cystic spaces. Hematoxylin and Eosin, x40

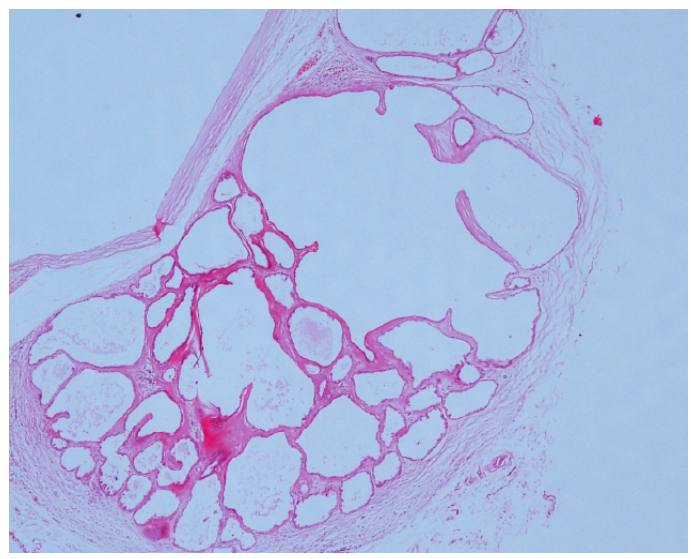

Figure 3. Cystic cavity seen lined by double layer cells; inner columnar epithelial cells and outer flattened myoepithelial cells. Hematoxylin and Eosin, x200

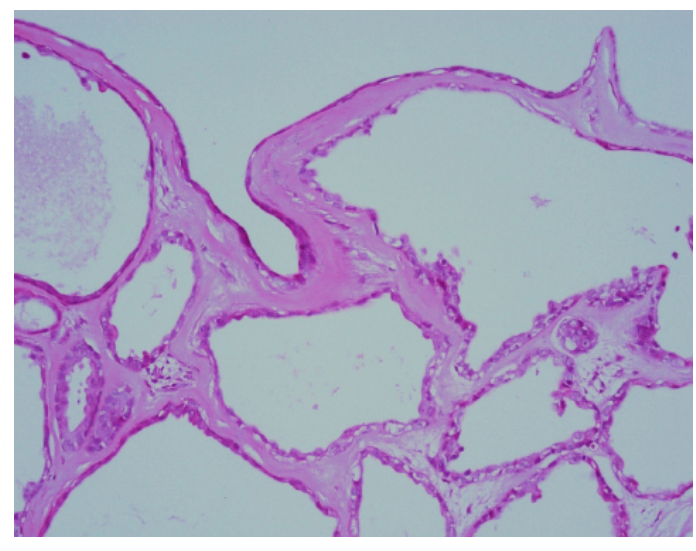

The clinical differential diagnosis includes eccrine hidrocystoma, cystic basal cell epithelioma, milium, and epidermoid or pilar cysts. In our patient, lesion was consisting of conglomerating, multiple vesicules so we thought it to be a lymphoprolipherative degeneration. The treatment of apocrine hidrocystoma is described in several case reports. The authors stated that successful management requires excision with removal of the cyst wall to prevent recurrence[7]. Ssi-Yan-Kai et all reported a recurrent giant orbital apocrine hidrocystoma of the eye and emphasised the importance of intact excision of these lesions. They indicated that, because of very thin cyst walls intact excision may be challenging but is nec- essary to avoid recurrence [8]. Recent reports have included case studies in which trichloracetic acid [9], carbon-dioxide lasers [10], and 1450-nm diode lasers [11] have been used for management.

\section{Conclusion}

Although it is extremely rare, apocrine hidrocyctoma must be kept in mind in differential diagnose, especially in vesicular lesions.

\section{References}

[1]. Vashi N, Mandal R (2010): Giant multi-loculated apocrine hidrocystomas. 
Dermatol Online J;16:16.

[2]. Alagheband M, Maida MF (2004): Asymptomatic periorbital, bluish cystic papule. Cortlandt Forum;17:36-41.

[3]. Ozel R, Kaynar A (2012): A case of an apocrine hidrocystoma treated by sublabial approach. Kulak Burun Bogaz Ihtis Derg;22:284-7.

[4]. Sarabi K, Khachemoune A (2006): Hidrocystomas - a brief review. MedGenMed; 8:57.

[5]. Ioannidis D, Drivas E (2009): Hidrocystoma of the external auditory canal: a case report. Cases J; 2:79.

[6]. D Vani, Dayananda T R, Shashidhar H B (2013): Multiple apocrine hidrocystomas: a case report. J ClinDiagnRes;7:171-2.

[7]. Armstrong AP, Lavery KM, Hollingsworth T (1996) : Apocrine hidrocys- toma: report of a case. Br J Oral Maxillofac Surg;34:335-7.

[8]. Ssi-Yan- Kai IC, Pearson AR (2012) : Recurrent giant orbital apocrine hidrocystoma. Eye (Lond);26:895-6.

[9]. Dailey RA, Saulny SM, Tower RN (2005) : Treatment of multiple apocrine hidrocystomas with trichloroaceticacid. Ophthal Plast Reconstr Surg;21:148-50.

[10]. Del Pozo J, Garcia-Silva J, Pena-Penabad C, Fonseca E (2001) : Multiple apocrine hidrocystomas: treatment with carbondioxide laser vaporization. J Dermatolog Treat;12:97-100.

[11]. Anandasabapathy N (2008): Multiple apocrine hidrocystomas. Dermatology Online Journal;14:12. 